\title{
Transfer cells in trichomatous nectary in Adenocalymma magnificum (Bignoniaceae)
}

\author{
THÁLIA S.S. GAMA ${ }^{1}$, ANA CRISTINA A. DE AGUIAR-DIAS ${ }^{2}$ and DIEGO DEMARCO ${ }^{1}$ \\ ${ }^{1}$ Universidade de São Paulo, Instituto de Biociências, Rua do Matão, 277, 05508-090 São Paulo SP, Brasil \\ ${ }^{2}$ Universidade Federal do Pará, Instituto de Ciências Biológicas, Rua Augusto Correa, 1, 66075-110 Belém, PA, Brasil \\ Manuscript received on January 14, 2015; accepted for publication on April 2, 2015
}

\begin{abstract}
Transfer cells are specialized cells that play an important role where there are high energy costs due to facilitation of transmembrane flow of solutes. This study aimed to investigate the ontogenesis, histochemistry and ultrastructure of glandular trichomes focusing on stalk cells and their possible transfer function. Samples of prophylls of axillary buds, calyces of flowers in anthesis, and flower buds in different stages of development were collected, fixed and processed according to the common methods of microscopy. The glandular trichomes are composed of a secretory head with its cells in columnar format. The stalk is formed by two layers of cells, with the upper layer composed of cuboidal cells where the wall starts to thicken at the beginning of the pre-secretory phase. The secretion is heterogeneous, releasing glucose, other carbohydrates, lipids and phenolic compounds, with two types of release - eccrine and granulocrine. These trichomes are functionally termed as nectaries. The stalk cells appear as transfer cells since they have a thicker anticlinal wall with irregular ingrowths. The presence of transfer cells in the nectaries suggests a high specialization because it improves transport capacity of nectar and compensation in the high energy expenditure for its production and release.
\end{abstract}

Key words: glandular trichomes, nectaries, ontogenesis, secretory structures, wall ingrowths.

\section{INTRODUCTION}

Transfer cells are highly specialized cells and occur in vegetative and reproductive organs, especially in places where the demand for an intensive transport of solutes through the membrane, is high (Gunning and Pate 1974).

For most cells, the primary wall is deposited uniformly over all faces of the cell during expansion (Carpita and Gibeaut 1993). When expansion is completed, some plant cells produce a thick secondary wall (Talbot et al. 2001). In

Correspondence to: Thália do Socorro Serra Gama

E-mail: thaliagama@gmail.com transfer cells the thickness of the secondary wall is not uniformly formed by invaginated projections, which characterize these cell types (Gunning and Pate 1974).

The deposition of these wall ingrowths amplifies the surface area of the plasma membrane, which hypothetically facilitates the transmembrane flow and exchange of solutions between apoplast and symplast (Pate and Gunning 1972). Because of this specialization, transfer cells are found in various organs, such as gametophytic cells (Diboll and Larson 1966, Cass 1972, Wilms 1981, Bohdanowicz and Turała-Szybowska 1985, 1987) and vascular tissues, specifically in the parenchyma 
cells of the xylem and companion cells of the phloem (Pate and Gunning 1969, Gunning et al. 1970, Talbot et al. 2002).

Transfer cells, due to their function of intensifying the transport of solutes over short distances, play a very important role in secretory structures that require this flow to release substances (Offler et al. 2003). These cells are common in different secretory tissues, such as nectaries, hydathodes and glands, in general (Fahn 1979a), because regions that are closely involved in secretion and absorption have this kind of cell as an integral part of their morphology (Dahiya and Brewin 2000). Research from Schnepf (1964) and Gunning and Pate (1969) revealed that the beginning of ingrowths are related to the physiological events of nectar secretion.

Nectaries are structures characterized by the secretion of a sugary and heterogeneous solution (Baker and Baker 1982, Nicolson et al. 2007). Among the compounds of this solution which require more energy for production, are lipids (Nicolson and Thornburg 2007). There are several works with nectaries in Bignoniaceae, of which the most comprehensive is that of Seibert (1948), Rivera (2000a, b), Gonzalez (2011) and Nogueira et al. (2013). Despite the large number of studies, little is known about the ontogeny and ultrastructure of these nectaries.

Previous anatomic studies in Adenocallyma Mart. ex Meisn. (e.g. Laroche 1974) showed the presence of a layer of cells with thickened anticlinal walls, which prompted this research. The goals of the current research were to analyze the ontogenesis, histochemistry and ultrastructure of glandular trichomes, focusing on stalk cells and their possible transfer function.

\section{MATERIALS AND METHODS}

BOTANICAL MATERIAL

Specimens of Adenocalymma magnificum Mart. ex DC. were collected along the road of Marudá city (PA-318) in the state of Pará, Brazil, for herborization and procedures in plant anatomy. Fresh prophylls of axillary buds (first to fifth node), calyx of the flower in anthesis, and flower buds in different stages of development were collected and fixed. Glucose paper strips were used to analyze the presence of glucose in the secretion. Voucher specimens were prepared and deposited in the herbarium João Murça Pires (MG 203513) and the glandular trichome morphology was classified based on Nogueira et al. 2013.

\section{LIGHT MICROSCOPY AND HISTOCHEMICAL TESTS}

For the anatomical analysis over light microscopy, samples were fixed in 50\% FAA and neutral buffered formalin for 24 and $48 \mathrm{~h}$, respectively, dehydrated in a butyl series (tertiary butyl alcohol; Johansen 1940), and embedded in Paraplast (Leica Microsystems Inc., Heidelberg, Germany). Cross and longitudinal sections $(8-13 \mu \mathrm{m})$ were made with the assistance of a rotary microtome and later stained with Safranin and Astra Blue (Gerlach 1984). The following histochemical tests were performed in fresh hand-cut sections: PAS reaction, to detect the presence of carbohydrates (McManus 1948); Sudan Black B, for lipids (Pearse 1980); Ferric Chloride, for phenolic compounds (Johansen 1940); and NADI for terpenoids (David and Carde 1964).

\section{ELECTRON MICROSCOPY}

The material designated for transmission electron microscopy (TEM) analysis was fixed in $2.5 \%$ glutaraldehyde for $24 \mathrm{~h}$, postfixed in $1 \%$ osmium tetroxide in $0.1 \mathrm{M}$ phosphate buffer for $2 \mathrm{~h}, \mathrm{pH}$ 7.2 , dehydrated in an acetone-solution series and embedded in Spurr resin (Roland 1978). Ultrathin sections were made and counterstained with uranyl acetate (Watson 1958) and lead citrate (Reynolds 1963 ) for further analysis on a Zeiss EM 900 electron microscope. 
The samples designated for scanning electron microscopy (SEM) analysis were fixed in 2.5\% glutaraldehyde in $0.1 \mathrm{M}$ phosphate buffer, $\mathrm{pH} 7.2$, dehydrated in an ethanol series, and critical-point dried (Robards 1978). The dried material was placed over aluminum stubs and examined using a LEO 1450 VP scanning electron microscope.

For confocal microscopy analysis, the samples were fixed in $50 \%$ FAA, clarified with sodium hypochlorite, and stained with $0.01 \%$ Acridine Orange (D. Demarco, personal communication).

\section{RESULTS}

\section{NECTARY STRUCTURE}

The glandular trichome found here is classified as patelliform, due to its disc-shaped morphology. The patelliform trichome occurs on vegetative and reproductive organs in all stages of development (Fig. 1a-b). Since the glucose paper test strips revealed the presence of glucose in the secretion of these trichomes, the nectary may be classified as a functional nectary.

The nectary is structurally a glandular trichome formed by one secretory head and stalk. The head consists of a secretory epidermis bi- or multistratified, presenting column format with a thin wall, while the stalk is formed by two layers of cells, in which the upper layer is comprised of cuboids cells with thick walls. The trichome is on the surface of the organ (Fig. 1c), with ordinary epidermal cells surrounding these trichomes (Fig. 1d-g) .

\section{ONTOGENESIS AND SECRETION}

The nectary presents asynchronic development and has protodermic origin. It begins from one cell which undergoes anticlinal division, forming a series of cells with columnar shape (Fig. 1c). Concomitantly, periclinal divisions occur, which form a row corresponding to the stalk cells (Fig. 1d-f). The stalk cells undergo asymmetric anticlinal division, originating a short stalk with wide cells and thin anticlinal walls. The anticlinal wall remains thin in order to begin the pre-secretory phase, thereafter these cells thicken.

The nectary, due to its protodermic origin, does not have direct vascular supply although phloem strands are observed two layers bellow of the stalk cell (Fig. 1g). In the secretory phase, the cuticle stretches in the central portion of the nectary and the anticlinal walls of stalk cells become thick (Fig. 1h-i).

The histochemistry analysis demonstrates the presence of carbohydrates, lipids and phenolic compounds on the nectariferous tissue (Fig. 1j-1).

\section{ULTRASTRUCTURAL ASPECTS}

The ultrastructure of secretory cells indicates that the vacuome is dispersed and has lipid drops (Fig. $2 \mathrm{a})$, mainly in the lower and upper region of the cell. Mitochondria, endoplasmic reticulum and leucoplasts (Fig. 2b) are abundant in these cells and are related to the secretory process. The dictyosomes (Fig. 2c) are not as representative at this stage when found close to the vesicles and cell wall.

Hydrophilic substances may have different release modes depending on the nectary region and are commonly released by projections in the wall cell (Fig. 2d); however, in the central region of the nectary was observed only disruption of the cuticle. Lipids and phenolic compounds are surrounded by a membrane, forming vesicles that fuse with the plasma membrane (Fig. 2e). The nectary remains intact after the release of both secretions.

The basal cells of the stalk show ultrastructural features of cytoplasm similar to those of the ordinary epidermal cells. However, plasmodesmata were seen between stalk cells, indicating that there was a route of substances via symplast (Fig. 3a).

The layer of stalk cells adjacent to the secretory cells is peculiar in this species, because these cells present thick anticlinal walls formed by ingrowths and present plasmodesmata in the periclinal walls, which connect the stalk cells to the secretory 

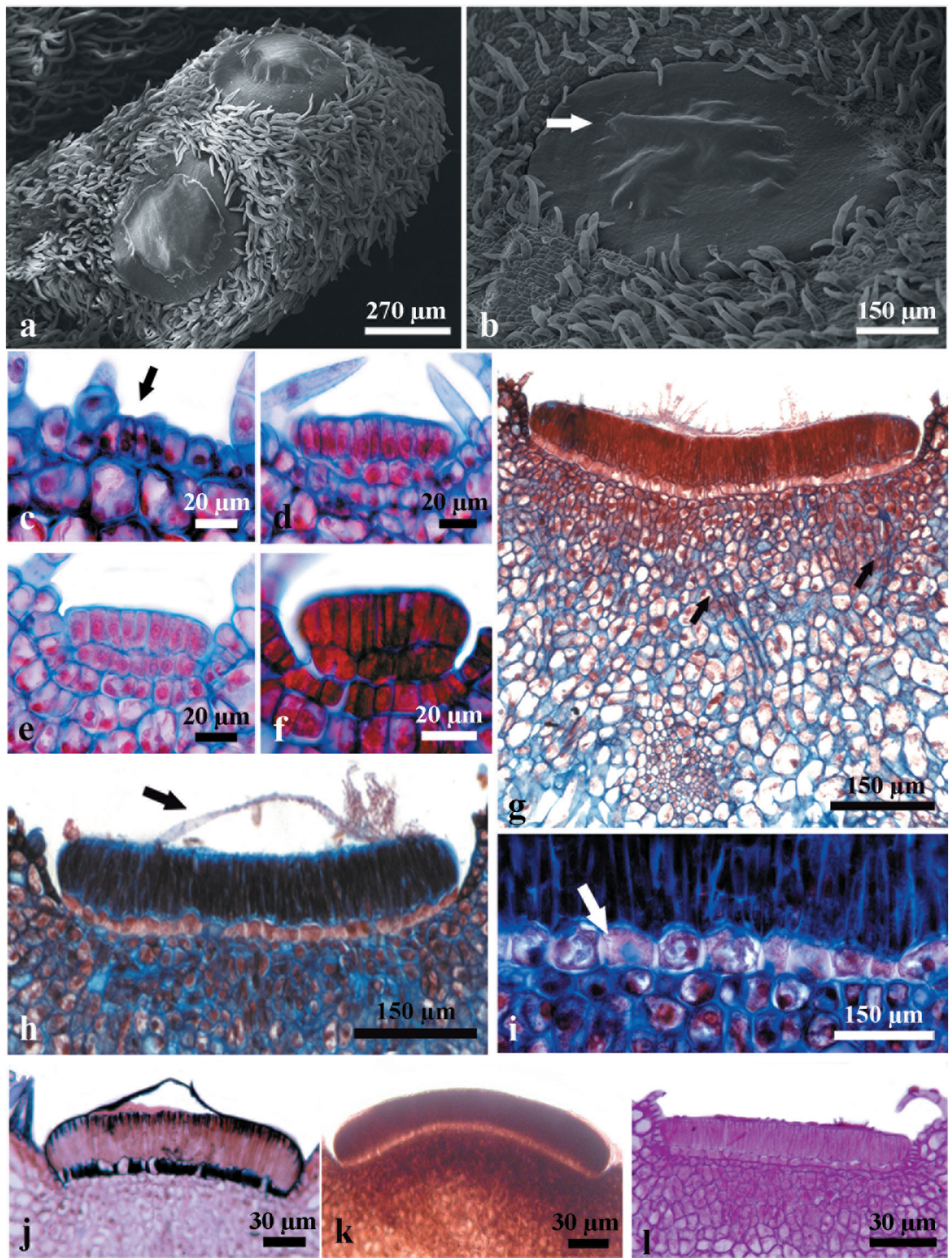

Figure 1 - Structure of the phases of development of the nectaries of Adenocalymma magnificum. (a,b) scanning electron microscopy; (a) nectary morphology on prophylls of axillary buds; (b) calyx of flower in anthesis, detail of the nectary in secretory phase (arrow). (c-f) development phases; (c) first phase; (d-f) intermediate phase showing anticlinal divisions of the stalk cells. (g-i) Adult nectary; (g) detail of phloem strands (arrow); (h) detail of disruption of the cuticle in the central portion (arrow); (i) detail of thicker anticlinal wall. (j-l) histochemistry tests; (j) sudan Black B; (k) ferric chloride; (I) PAS reaction (see the colors in the online version). 

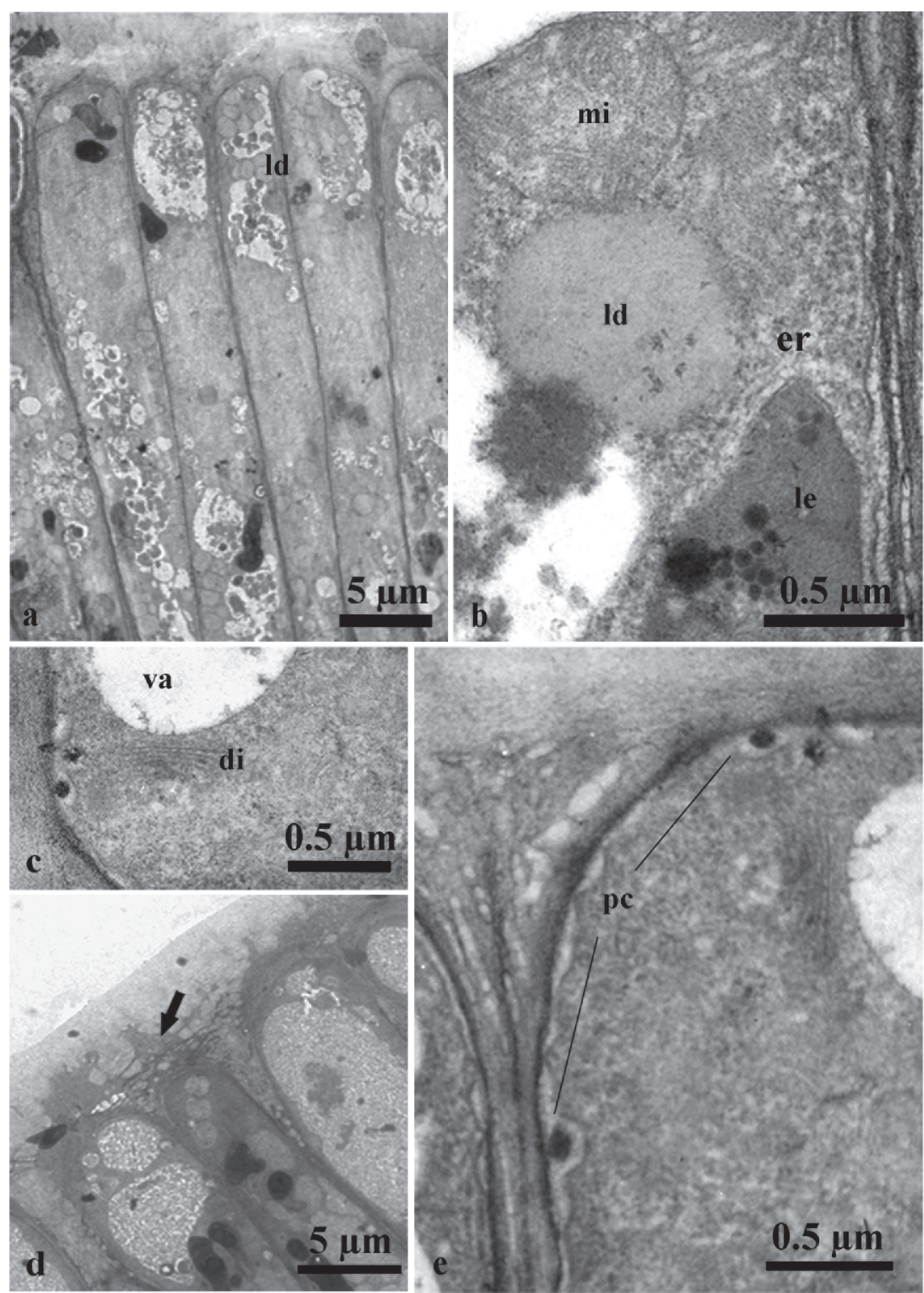

Figure 2 - Aspects of the ultrastructure of nectaries of Adenocalymma magnificum. Secretory cells. (a) secretory cells in palisade, showing lipid droplets; (b) most representative organelles in these cells, mitochondria, endoplasmic reticulum and leucoplasts; (c) dictyosomes close to the vesicles; (d) projections of the wall cell into the cuticle (arrow); (e) vesicles releasing phenolic compounds. Abbreviations: (di) dictyosomes, (er) endoplasmic reticulum, (ld) lipid droplets, (le) leucoplasts, (mi) mitochondria, (pc) phenolic compounds, (va) vacuole. 
cells (Fig. 3a). Having this morphology, they are functionally called transfer cells. The transfer cells present a dispersed vacuome with electron- dense content (Fig. 3b) and many mitochondria concentrated along the outer periclinal wall next to the secretory cells (Fig. 3c).
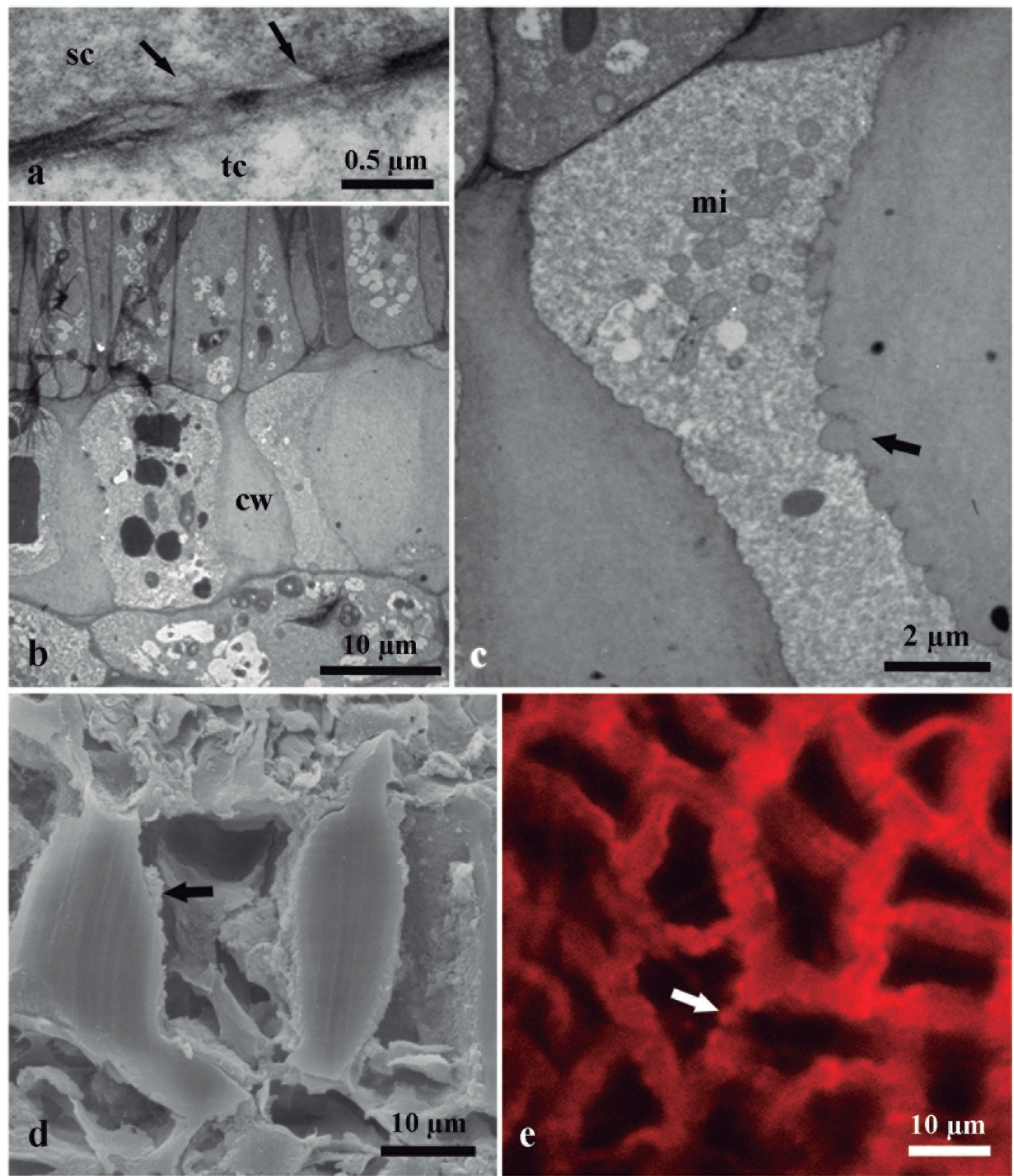

Figure 3 - Aspects of the structure of transfer cells of Adenocalymma magnificum. (a-c) Transmission electron microscopy; (a) plasmodesmata between stalk cells and secretory cells (arrow); (b) dispersed vacuome with electron-dense content; (c) agglomerate of mitochondria in transfers cells, detail of wall ingrowths (arrow); (d) scanning electron microscopy of wall ingrowths formed by small papillae (arrow); (e) overview of papillae in transfer cell walls using confocal microscopy (arrow). Abbreviations: (cw) cell wall, (mi) mitochondria, (sc) secretory cell, (tc) transfer cell (see the colors in the online version). 


\section{INGROWTH CHARACTERISTICS}

The wall ingrowths are characterized as reticulate, as deposition begins with the formation of small papillae, which can present different sizes according to their development. Those occurring in A. magnificum emerge from the secondary wall and occasionally merge with neighboring papillae, but this process does not culminate in a complex labyrinthine network (Fig. 3d, e).

\section{DISCUSSION}

The presence of glucose in the secretion of trichomes of $A$. magnificum makes this structure be a nectary, as seen in another species of Bignoniaceae (e.g. Belmonte et al. 1994, Rivera 2000, Lopes et al. 2002, Nogueira et al. 2013). However, in $A$. magnificum different events occur simultaneously, which were understood by the manner in which a heterogeneous secretion was released in the presence of chemical substances produced by various metabolic pathways, unique to secretory structures. The sugars from phloem are largely transferred by the stalk cells and then released by wall projections. The molecules cross the plasma membrane of the secretory cells as a result of a concentration gradient or active process (Fahn 1979b), which also occurs in Gasteria and in some other Liliaceae (Schnepf 1964, Lüttge and Schnepf 1976). This possibility of active transport of sugars into the nectary of Abutilon was discussed by Findlay et al. (1971).

In A. magnificum the lipid substances are secreted by vesicles into the external environment by exocytosis, this mode of transport is classified as granulocrine secretion. The process of fusion between membranes and plasmalemma was observed by Fahn (1988).

In the secretory cells, some organelles were quite evident, such as mitochondria, which is involved in energy production (Nepi 2007), and leucoplasts and endoplasmic reticulum, which are the two organelles involved in the production of lipids of A. magnificum. Although the endoplasmic reticulum is involved in this production, it is possible that it is also related to the transport of nectar inside the cell. According to Heinrich (1975), this organelle actively participates in the transport of nectar in Aloe, where there is high ATPase activity, nucleoside diphosphatase, and glucose-6-phosphatase in the endoplasmic reticulum of nectaries and generally no activity of these phosphatases in the plasma membrane. The same is supported by Fahn (2000) and Stpiczyńska et al. (2005), who state that the predominance of smooth reticulum is associated with lipid metabolism. Another organelle noticed was the dictyosome, which are associated with the release of nectar (Fahn 1979b, Kronestedt-Robards et al. 1986, Sawidis et al. 1987, 1989).

Studies have indicated that transfer cells exist in these nectaries, which facilitate the transport of solutes over short distance by transmembrane flow (Pate and Gunning 1972). Transfer cells are apparently restricted to situations where the areavolume correlations are not equivalent (i.e., the area is smaller than the volume) or when the solute transported is accompanied by a minimum flow of solvent. The presence of these specialized cells suggests that selection pressures of a physiological nature may have shaped the evolution of the transfer cell (Gunning and Pate 1969).

Morphologically, transfer cells found in this study appear with thin anticlinal walls at certain times and with thick walls at posterior times. The onset of wall thickening occurs when the glandular cells are in the pre-secretory phase. This information corroborates the conclusions of Schnepf (1964), who states that the proliferation of the cell ingrowths is related to physiological events in nectar secretion of Gasteria, in which cell wall thickening begins when it is in the pre-secretory phase and ends in the secretory phase, followed by degeneration and reabsorption in the post-secretory phase. 
Observations about the secretory cells of the extrafloral nectary of Vicia faba L. lead to the conclusion that invaginations are not formed until the start of sugar secretion (Gunning and Pate 1969). In contrast, the post-secretory stage cell wall underwent redifferentiation in Gasteria and Aloe; ingrowths disappeared and the cell wall became covered by a "third layer" (Schnepf and Pross 1976).

Generally, transfer cells are highly polarized and develop only in areas where there is intensive transmembrane transport activity, e.g., areas bordering xylem elements or adjacent to sieve tubes, companion cells, in addition to adjacent intercellular spaces (Pate and Gunning 1972). Due to the functionality promoted by ingrowths, it is common to find them in secretory cells. Several studies of nectaries have reported the presence of these cells, e.g., perigonal nectaries of Fritillary (Stpiczyńska et al. 2012) and septal nectaries of Tillandsia (Fiordi and Panandri 1982), Gasteria, Aloe (Schnepf and Pross 1976), Strelitzia (Kronestedt-Robards and Robards 1987) and at the nectariferous parenchyma of Eccremocarpus scarber from Bignoniaceae (Belmonte et al. 1994).

According to Gunning (1977), almost all invaginate cell walls are closely associated with mitochondria, suggesting the involvement of high ATPase activity during transport of solutes across the membrane (Maier and Maier 1972, Joshi et al. 1993). Thus, the efficient transport of substances by transfer cells in A. magnificum is confirmed by the presence of several mitochondria found within these cells, which are supposed to produce energy to pump the secretion into the secretory cell. The hypothesis that these cells are involved only in the solution transport with sugar is strongly supported in a study by Schnepf (1969) which showed that the invaginations are rarely found in systems where the secretion occur by vesicles. However, ingrowths supporting eccrine secretions often occur (Schnepf 1961, 1969).
Descriptive observations of transfer cells in many species revealed different types of ingrowth morphologies (Gunning 1977), these types are grouped in two categories, called "flange" and "reticulate" (Talbot et al. 2002). In most transfer cells, the formation of ingrowth occurs by the appearance of small papillae on the wall, which then develop branches and merge, forming complex networks; this pattern is called reticulate (Gunning and Pate 1969, Talbot et al. 2002). However, there is another method of deposition of ingrowths in which these invaginations are apparently similar to ridge projections, such as sided cords (Davis et al. 1990) or flanges, which generally resemble secondary wall thickenings of some tracheary elements (Zee and O'Brien 1971). In A. magnificum the type of deposition is reticulate, although the invaginations do not develop interconnected networks with wall material, which is similar to the initial stages of deposition of transfer cells in other species, such as transfer cells of xylem parenchyma in the roots of Vicia faba L. (Talbot et al. 2002).

The presence of transfer cells is described here for the first time in nectaries of Bignoniaceae. These transfer cells are the same stalk cells which eventually assumed the role of transporting sugar through the transmembrane flow. It was also seen that, concomitantly with the nectar secretion, lipophilic compounds occur, classified as heterogeneous secretion, with two types of release - eccrine and granulocrine. The production of lipophilic compounds is generated from a high energy outflow of the plant(Nicolson and Thornburg 2007), justifying the presence of the ingrowths in the cell wall, and producing specialized cells (Stpiczyńska et al. 2012).

\section{ACKNOWLEDGMENTS}

Our data was supplemented by the results obtained from the first author's master research project and the diploma dissertation. We are grateful to the technicians from the Electron Microscopy 
Center of the Museu Paraense Emílio Goeldi and Universidade de São Paulo for their assistance.

\section{RESUMO}

As células de transferência são células especializadas que desempenham um papel importante onde há altos custos de energia devido a facilitação do fluxo transmembranar de solutos. Esse estudo objetivou investigar a ontogênese, histoquímica e ultraestrutura dos tricomas glandulares focando nas células do pedúnculo e suas possíveis funções de transferência. Amostras de profilos da gema axilar, cálices das flores em antese, e botões florais em diferentes estágios de desenvolvimento foram coletados, fixados e processados de acordo com os métodos usuais de microscopia. Os tricomas glandulares são compostos de uma cabeça secretora com suas células em formato colunar. O pedúnculo é formado por duas camadas de células, a camada superior compreende células cuboidais, onde a parede começa a se espessar no início da fase présecretora. A secreção é heterogênea, liberando glicose, outros carboidratos, lipídeos e compostos fenólicos, com dois tipos de liberação - écrina e granulócrina. Estes tricomas são funcionalmente denominados nectários. As células do pedúnculo são consideradas células de transferência por possuírem parede anticlinal mais espessa com invaginações irregulares. A presença de células de transferência nos nectários sugere uma alta especialização, pois isso aumenta a capacidade de transporte de néctar e a compensação do alto gasto de energia para a produção e liberação dessa substância.

Palavras-chave: tricomas glandulares, nectários, ontogênese, estruturas secretoras, invaginação na parede.

\section{REFERENCES}

BAKER HG AND BAKER I. 1982. Chemical constituents of nectar in relation to pollination mechanisms and phylogeny. In: Nitecki MH (Ed), Biochemical aspects of evolutionary biology, Chicago: University of Chicago Press, USA, p. 131-171.

BELMONTE E, CARDEMIL L AND ARROYO MTK. 1994. Floral nectary structure and nectar composition in Eccremocarpus scaber (Bignoniaceae), a hummingbird-pollinated plant of central Chile. Am J Bot 81(4): 493-503.

BOHDANOWICZ J AND TURAŁA-SZYBOWSKA K. 1985. Ultrastructure of endopolyploid antipodals in Aconitum vulparia Rchb. I. Antipodals in the mature embryo sac. Protoplasma 127: 163-170.
BOHDANOWICZ J AND TURAŁA-SZYBOWSKA K. 1987. Ulrastructure of endopolyploid antipodals in Aconitum vulparia Rchb. II. Antipodals in the period of free nuclear endosperm. Protoplasma 140: 13-21.

CARPITA NC AND GIBEAUT DM. 1993. Structural models of primary cell walls in flowering plants: consistency of molecular structure with the physical properties of the walls during growth. Plant J 3(1): 1-30.

CASS DD. 1972. Occurrence and development of a filiform apparatus in the egg of Plumbago capensis. Am J Bot 59(3): 279-283.

DAHIYA P AND BREWIN NJ. 2000. Immunogold localization of callose and other cell wall components in pea nodule transfer cells. Protoplasma 214: 210-218.

DAVID R AND CARDE JP. 1964. Coloration différentielle dês inclusions lipidique et terpeniques dês pseudophylles du Pin maritime au moyen du reactif Nadi. Compt Rend Hebd Seances Acad Sci 258: 1338-1340.

DAVIS RW, SMITH JD AND COBB BG. 1990. A light and electron microscope investigation of the transfer cell region of maize caryopses. Can J Bot 68(3): 471-479.

DIBOLL AG AND LARSON DA. 1966. An electron microscopic study of the mature megagametophyte in Zea mays. Am J Bot 53(4): 391-402.

FAHN A. 1979a. Secretory tissues in plants. New York: Academic Press, New York, USA, 302 p.

FAHN A. 1979b. Ultrastructure of nectaries in relation to nectar secretion. Am J Bot 66(8): 977-985.

FAHN A. 1988. Secretory tissues in vascular plants. New Phytologist 108: 229-257.

FAHN A. 2000. Structure and function of secretory cells. Adv Bot Res 31: 37-75.

FINDLAY N, REED ML AND MERCER FV. 1971. Nectar production in Abutilon. III. Sugar secretion. Aust J Biol Sci 24: 665-675.

FIORDI AC AND PANANDRI MR. 1982. Anatomic and ultrastructural study of septal nectary in some Tillandsia (Bromeliaceae) species. Caryologia 35(4): 477-489.

GERLACH D. 1984. Botanische Mikrotechnik. Stuttgart: Georg Thieme Verlag, Baden-Württemberg, Germany, 262 p.

GONZALEZ AM. 2011. Domacios y nectarios extraflorales en Bignoniáceas: componentes vegetales de una interacción mutualística. Boletín de la Sociedad Argentina de Botánica 46(3-4): 271-288.

GUNNING BES. 1977. Transfer cells and their roles in transport of solutes in plants. Sci Prog (Oxford) 64: 539-568.

GUNNING BES AND PATE JS. 1969. "Transfer cells": plant cells with wall ingrowths, specialized in relation to short distance transport of solutes - their occurrence, structure, and development. Protoplasma 68: 107-133.

GUNNING BES AND PATE JS. 1974. Transfer cells. In: Robards AW (Ed), Dynamic Aspects of Plant Structure. London: McGraw-Hill, London, England, p. 441-479. 
GUNNING BES, PATE JS AND GREEN LW. 1970. Transfer cell in the vascular system of stems: taxonomy, association with nodes, and structure. Protoplasma 71: 147-171.

HEINRICH G. 1975. Über die Lokalisation verschiedener Phosphatasen im Nektarium von Aloe. Cytobiologie 11: 247-263.

JOHANSEN DA. 1940. Plant microtechnique. New York: McGraw Hill Book Company Inc., New York, USA, 523 p.

Joshi PA, CAETANo-Anolles G, GRAHAM ET AND GRESSHOFF PM. 1993. Ultrastructure of transfer cells in spontaneous nodules of alfalfa (Medicago sativa). Protoplasma 172: 64-76.

KRONESTEDT-ROBARDS E AND ROBARDS AW. 1987. Sugar secretion from the nectary of Strelitzia: an ultrastructural and physiological study. Protoplasma 137: 168-182.

KRONESTEDT-RobARDS EC, ROBARDS AW, STRAK M AND OLESEN P. 1986. Development of trichomes in the Abutilon nectary gland. Nord J Bot 6: 627-639.

LAROCHE RC. 1974. Anatomic Considerations of the Calyx of Adenocalymma comosum (Cham.) A.P. DC. Ann Missouri Bot Gard 61(2): 530-533.

Lopes AV, VoGel S AND MACHAdo IC. 2002. Secretory trichomes, a substitutive floral nectar source in Lundia A.DC. (Bignoniaceae), a genus lacking a functional disc. Ann Bot 90: 169-174.

LÜTTGE U AND SCHNEPF E. 1976. Elimination processes by glands: organic substances. In: Lüttge $\mathrm{U}$ and Pitman $\mathrm{MG}$ (Eds), Encyclopedia of Plant Physiology New Series. New York: Springer, Berlin Heidelberg, New York, USA, p. 244-277.

MAIER K AND MAIER U. 1972. Localization of beta-glycerophosphate and $\mathrm{Mg}$-activated adenosine triphosphatase in a moss haustorium, and the relation of these enzymes to the cell wall labyrinth. Protoplasma 5: 91-112.

MCMANUS JFA. 1948. Histological and histochemical uses of periodic acid. Stain Technol 23: 99-108.

NEPI M. 2007. Nectary Structure and Ultrastructure. In: Nicolson SW, Nepi M and Pacini E (Eds), Nectaries and Nectar. Dordrech: Springer, Drechtsteden, Netherland, p. 129-166.

NiCOLSON S AND THORNBURG RW. 2007. Nectar Chemistry. In: Nicolson SW, Nepi M and Pacini E (Eds), Nectaries and Nectar. Dordrech: Springer, Drechtsteden, Netherland, p. 215-264.

NiCOLSON SW, NEPI M AND PACINI E. 2007. Nectaries and nectar. Dordrech: Springer, Drechtsteden, Netherland, 395 p.

Nogueira A, El Ottra JH, Guimarães E, MACHAdo SR AND LOHMANN LG. 2013. Trichome structure and evolution in Neotropical lianas. Ann Bot 112: 1331-1350.

OFFler CE, MCCURdy DW, PATRICK JW AND TALBOT MJ. 2003. Transfer cells: cells specialized for a special purpose. Annu Rev Plant Biol 54: 431-454.
PATE JS AND GUNNING BES. 1969. Vascular transfer cells in Angiosperm leaves- a taxonomic and morphological survey. Protoplasma 68: 135-156.

PATE JS AND GUNNING BES. 1972. Transfer cells. Ann Rev Plant Physio 23: 173-196.

PEARSE AGE. 1980. Histochemistry theoretical and applied: preparative and optical technology. Edinburgh: Churchill Livingston, Edinburgh, 439 p.

REYNOLDS ES. 1963. The use of lead citrate at high $\mathrm{pH}$ as an electron-opaque stain in electron microscopy. J Cell Biol 17: 208-212.

RIVERA GL. 2000a. Nectarios extranupciales florales en especies de Bignoniaceae de Argentina. Darwiniana 38: 1-10.

RIVERA GL. 2000b. Nuptial nectary structure of Bignoniaceae from Argentina. Darwiniana 38(3-4): 227-239.

ROBARDS AW. 1978. An introduction to techniques for scanning electron microscopy of plant cells. In: Hall JL (Ed), Electron Microscopy and Cytochemistry of Plant Cells. New York: Elsevier, New York, USA, p. 343-403.

ROLAND JC. 1978. General preparations and staining of thin sections. In: Hall JL (Ed), Electron Microscopy and Cytochemistry of Plant Cells. New York: Elsevier, New York, USA, p. 1-60.

SAWIDIS T, ELEFTHERIOU EP AND TSEKOS I. 1987. The floral nectaries of Hibiscus rosa sinensis L. II. Plasmodesmatal frequences. Phyton 27: 155-164.

SAWIDIS T, ELEFTHERIOU EP AND TSEKOS I. 1989. The floral nectaries of Hibiscus rosa-sinensis III. A morphometric and ultrastructural approach. Nord J Bot 9: 63-71.

SCHNEPF E. 1961. Licht- und Elektronmikroskopische Beobachtungen an Insektivoren-Drüsen über die Sekretion des Fangschleimes. Flora 151: 73-87.

SCHNEPF E. 1964. Zur Cytologie und Physiologie pflanzlicher Drüsen. Protoplasma 58: 193-219.

SCHNEPF E. 1969. Sekretion und exkretion bei pflanzen. Protoplasmatologia, Handbuch der Protoplasmaforschung 8: 1-181.

SCHNEPF E AND PROSS E. 1976. Differentiation and redifferentiation of a transfer cell: development of septal nectaries of Aloe and Gasteria. Protoplasma 89: 105-115.

SEIBERT RJ. 1948. The use of glands in a taxonomic consideration of the family Bignoniaceae. Annals of the Missouri Botanical Garden 35: 123-137.

STPICZYŃSKA M, DAVIES KL AND GREGG A. 2005. Comparative account of nectary structure in Hexisea imbricata (Lindl.) Rchb.f. (Orchidaceae). Ann Bot 95: 749-756.

STPICZYŃSKA M, NEPI M AND ZYCH M. 2012. Secretion and composition of nectar and the structure of perigonal nectaries in Fritillaria meleagris L. (Liliaceae). Plant Syst Evol 298: 997-1013.

TALBOT MJ, FRANCESCHI VR, MCCURDY DW AND OFFLER CE. 2001. Wall ingrowth architecture in epidermal cells of Vicia faba cotyledons. Protoplasma 215: 191-203.

TALBOT MJ, OFFLER CE AND MCCURDY DW. 2002. Transfer cell wall architecture: a contribution towards under- 
standing localized wall deposition. Protoplasma 219: 197209.

WATSON ML. 1958. Staining of tissue sections for electron microscopy with heavy metals. J Biophys Biochem Cy 4(4): 475-478.
WILMS HJ. 1981. Ultrastructure of the developing embryo sac of spinach. Acta Bot Neerl 30: 75-99.

ZEE SY AND O'BRIEN TP. 1971. Vascular transfer cells in the wheat spikelet. Aust J Biol Sci 24: 35-49. 
